MAGDALENA MAKÓWKA

Uniwersytet Łódzki

(iD) ORCID ID: 0000-0003-0447-832X
WŁA DZA I POLITYKA

W CZASACH NOWOŻYTNYCH DYPLOMACJA I SPRAWY WEWNĘTRZNE

\title{
Dyplomacja brytyjska wobec hiszpańskiego zaangażowania w wojnę o sukcesję polską (1733-1735)
}

British diplomacy towards Spanish involvement in the war of Polish succession (1733-1735)

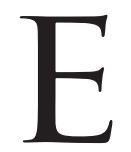

lekcja po śmierci Augusta II (1 II 1733) wywołała nieoczekiwane konsekwencje w całej Europie. Spór o to, czy władcą Rzeczypospolitej winien zostać wybrany Stanisław Leszczyński, czy też syn zmarłego króla Fryderyk August, stał się pretekstem do wojny, w którą zaangażowały się najważniejsze mocarstwa. Celem niniejszego artykułu nie jest przedstawienie konfliktu rozgrywającego się na wszystkich teatrach działań wojennych ${ }^{1}$, a jedynie zaprezentowanie punktu widzenia Wielkiej Brytanii na zaangażowanie się w tenże konflikt Hiszpanii. Podjęta zostanie również próba oceny skuteczności działań prowadzonych wobec państwa Filipa $\mathrm{V}$ w trakcie toczącego się konfliktu. Podstawę źródłową pracy stanowi korespondencja dyplomatyczna kierowana przez wysłannika Albionu do kraju na Półwyspie Iberyjskim Benjamina Keene’a oraz listy pisane do niego, głównie przez sekretarza stanu do spraw południowych Thomasa Pelhama księcia Newcastle.

Wielką Brytanię oraz cesarza od 1731 r. łączył traktat wiedeński, w którym obie strony zobowiązywały się do udzielenia sobie wzajemnego wsparcia. Od roku 1731 do 1733 relacje Albionu z Karolem VI uległy jednak znacznemu osłabieniu. Powodem był chociażby brak wsparcia ze strony cesarza do roszczeń Hanoweru w Rzeszy oraz, zdaniem Jerzego II, zbyt propruska postawa Austriaka. Dodatkowo punktem spornym było stanowisko cesarza względem terytoriów włoskich. Brytyjczycy chcieli, aby Habsburg i Filip V doszli do porozumienia, o jego brak obwiniali zaś opór cesarza. Geneza konfliktu Hiszpanii z cesarzem o ziemie włoskie sięga traktatu utrechckiego, na

\footnotetext{
${ }^{1}$ Szczegółowo kwestie związane z działaniami wojennymi na wszystkich teatrach omówił J. Sutton, Wojna o sukcesjępolską 1733-1735, Oświęcim 2015.
} 
mocy którego po zakończeniu wojny o sukcesję hiszpańską terytoria Hiszpanii w Italii przypadły w udziale Karolowi VI. W momencie śmierci Augusta II Wielka Brytania była gotowa wyłożyć pewne sumy na łapówki, które mogły zapewnić korzystny dla Karola VI wynik elekcji, lecz nie chciała angażować się w działania militarne ${ }^{2}$. Stało to w sprzeczności z zawartym w 1731 r. traktatem z Wiednia ${ }^{3}$. Następne dwa lata przyniosły jednak ochłodzenie wzajemnych relacji, co wynikało z niechęci Karola VI do spełnienia oczekiwań terytorialnych Jerzego II jako władcy Hanoweru, zbliżenia austriacko-pruskiego oraz braku powiązań gospodarczych, kulturalnych czy nawet religijnych pomiędzy sojusznikami ${ }^{4}$.

W chwili wybuchu konfliktu Karol VI oczekiwał wsparcia Wielkiej Brytanii. W Albionie procesarskie sympatie wykazywał chociażby książę Newcastle ${ }^{5}$ Zdaniem części badaczy chętnym do udzielenia pomocy cesarzowi był również Jerzy II. Miał on chcieć wspierać cesarza chociażby ze względu na poczucie obowiązku, jakie ciążyło na nim jako księciu Rzeszy. Taki też obraz postawy króla przekazał w swych pamiętnikach J. Hervey. Autor biografii władcy Andrew Thompson przedstawia jednak bardziej zniuansowany obraz postawy monarchy, który miał zdawać sobie sprawę z tego, że wysłanie wojsk na pomoc Habsburgowi osłabi obronę Hanoweru, o którego bezpieczeństwo władca miał się obawiać6.

Wielka Brytania dążyła do powstrzymania konfliktu, starając się przekonać cesarza do ustępstw w kwestii elekcji króla polskiego. Dyplomacja Albionu zachęcała Karola VI do odstąpienia od granicy polskiej, licząc, że zapobiegnie to wybuchowi wojny ${ }^{7}$. Cesarz nie zdecydował się jednak skorzystać z rady sojusznika ${ }^{8}$.

W roku 1733 główną rolę w brytyjskiej dyplomacji w Hiszpanii odgrywał Benjamin Keene. Od 1724 r. przebywał w Madrycie jako konsul generalny, w 1727 jako minister

\footnotetext{
${ }^{2}$ Kwestia ogólnego stosunku Wielkiej Brytanii do wojny z lat 1733-1735 została omówiona przez brytyjskich historyków. Por. J. Black, British neutrality in the war of the Polish succession, 1733-1735, „International History Review" 1986, vol. VIII, No. 3, s. 345-366. https://doi.org/10.1080/07075332.198 6.9640416; R. Lodge, English neutrality in the war of the polish succession: A commentary upon diplomatic instructions, vol. VI, France, 1727-1744, „Transactions of the Royal Historical Society” 1931, vol. XIV, s. 141-173. https://doi.org/10.2307/3678511

3 Por. J. Black, Anglo-Austrian relations, 1725-1740. A study in Failure, „Journal for Eighteenth Century Studies" 2008, vol. XII, No. 1, s. 36. https://doi.org/10.1111/j.1754-0208.1989.tb00043.x

${ }^{4}$ Idem, British Neutrality, s. 349-351.

5 Idem, Anglo-Austrian, s. 37.

6 A. Thompson, George II, London 2012, s. 104-105.

7 R. Lodge, English neutrality, s. 150-151.

${ }^{8} \mathrm{Na}$ temat postawy Habsburgów wobec elekcji z roku 1733 por. J. Dygdała, Dylematy austriackiej polityki wobec Rzeczypospolitej podczas bezkrólewia 1733 r., „Acta Universitatis Nicolai Copernici. Historia” 1993, t. XXVIII, nr 259, s. 103-124; W. Strobl, Österreich und der polnische Thron 1733, Wien 1950 (nieopublikowana rozprawa doktorska).
} 
pełnomocny negocjował zaś warunki traktatu w Sewilli. W roku 1734 otrzymał nominację na ambasadora nadzwyczajnego w Hiszpanii. Był to więc dyplomata doświadczony, znający meandry hiszpańskiej polityki'.

Ważną rolę w decyzji o zaangażowaniu się Hiszpanii w konflikt z cesarzem odegrała również królowa Elżbieta Farnese. Poślubiła króla w roku 1715, a rok później urodziła pierwszego syna Karola ${ }^{10}$. Żona monarchy, zdając sobie sprawę z tego, że jej potomek znajduje się w kolejce do sukcesji dopiero za infantami urodzonymi z pierwszego małżeństwa króla, pragnęła zdobyć dla niego posiadłości we Włoszech ${ }^{11}$. Pierwszą próbą podjętą przez Hiszpanię, mającą na celu odebranie Karolowi VI posiadłości w Italii, była wojna z lat 1717-1720, którą rozpoczęło zajęcie Sardynii oraz Sycylii1 ${ }^{12}$. Ostatecznie konflikt ten zakończył się dla państwa Filipa V wojną z koalicją Wielkiej Brytanii, cesarza oraz Francji. Hiszpańskim Burbonom w wyniku konfrontacji udało się jednak uzyskać gwarancję sukcesji w Parmie i Piacenzy oraz Toskanii ${ }^{13}$.

Mniej istotną rolę w polityce Hiszpanii odgrywał król Filip V. Monarcha w trakcie swego panowania niejednokrotnie miewał ataki melancholii, które utrudniały mu funkcjonowanie. W 1724 r. władca zdecydował się abdykować na rzecz swojego syna Ludwika, który jednak zmarł po kilku miesiącach. Król Filip V w roku 1733 doznał kolejnego napadu melancholii, dlatego też jego możliwości podejmowania decyzji były ograniczone, mimo że latem władca czuł się coraz lepiej ${ }^{14}$.

Czołowym politykiem hiszpańskim 1726 r. pozostawał José Patiño. Pochodził z galicyjskiej rodziny. Skumulował w swych rękach większość najważniejszych urzędów, jednak jego pozycja nadal zależała w dużym stopniu od poparcia królowej, dlatego też starał się realizować w polityce jej interesy. Pozycja Patiño jest jednak nie do przecenienia, zwłaszcza w momentach pogarszającej się kondycji psychicznej władcy ${ }^{15}$.

Brytyjski dyplomata na hiszpańskim dworze pilnie śledził wszelkie przejawy francuskiej aktywności na Półwyspie Iberyjskim. Keene w sierpniu 1733 r. spodziewał się podpisania porozumienia między Hiszpanią a Francją, lecz jednocześnie w wysłanej

9 M.J. Mercer, Keene, Sir Benjamin, [w:] ODNB, https://www.oxforddnb.com/view/10.1093/ ref:odnb/9780198614128.001.0001/odnb-9780198614128-e-15245?rskey=OIJS8L\&result=1 (dostęp: 26.10.2020).

$10 \mathrm{~W}$ niniejszym artykule występuje on pod hiszpańską wersją imienia don Carlos.

11 H. Kamen, Philip V of Spain. The King who Reigned Twice, London 2001, s. 103-104.

12 Atak na Sycylię nastąpił w lipcu 1718 r., wyspa znajdowała się wówczas we władaniu Domu Sabaudzkiego. Por. F. Dhondt, "Arrestez et pillez contre toute sorte de droit”: trade and the war of the Quadruple Alliance (1718-1720), „The Journal for Renaissance and Early Modern Diplomatic Studies” 2017, No. 1, s. 102-103. https://doi.org/10.12775/LEGATIO.2017.04

13 W 1731 r. władzę przejął tam trzeci syn Filipa V - don Carlos.

${ }^{14}$ H. Kamen, Philip V of Spain, s. 140-143, 194.

15 A. Kuethe, K. Andrien, War and Reform, 1736-1749. The Spanish Atlantic World in the Eighteenth Century, Cambridge 2014, s. 98-103. https://doi.org/10.1017/CBO9781107338661 
korespondencji zaznaczał, że są to tylko jego podejrzenia. Francuska dyplomacja kierowana przez kardynała Fleury od wiosny 1733 r. dążyła do włączenia państwa Filipa V do konfliktu. Negocjacje w tej sprawie przeciągały się między innymi przez nadmierne oczekiwania ze strony królowej Elżbiety ${ }^{16}$.

Brytyjczycy tymczasem (latem 1733 r.) czynili pewne starania na rzecz ochrony interesu cesarza. Wysłannik dworu św. Jakuba rozmawiał z ministrem Patiño o tym, czy Karol VI musi obawiać się zagrożenia ze strony Hiszpanii. Jego rozmówca miał zaprzeczyć, ażeby państwo Filipa $\mathrm{V}$ miało w planach wystąpienie przeciwko Habsburgowi ${ }^{17}$. Brytyjski przedstawiciel w Hiszpanii w sierpniu 1733 r. nie był jeszcze pewien, jak potoczą się relacje hiszpańsko-habsburskie. Zauważał, że kraj leżący na Półwyspie Iberyjskim wysłał do Wiednia jako ambasadora jednego z bardziej wpływowych dworzan. Zdaniem Keene'a miał to być znak, że Hiszpanie nie podjęli jeszcze decyzji o zaangażowaniu się w zbliżający się konflikt po stronie Francji ${ }^{18}$. Uwadze brytyjskiej dyplomacji nie umknął jednocześnie fakt, że ambasador Francji Rottenbourg jest częstym gościem na dworze w San Idefonso; w korespondencji dyplomatycznej znalazła się informacja, iż codziennie bywał u ministrów, z którymi prowadził długie rozmowy $y^{19}$. Patiño, rozważając ewentualny udział Hiszpanii w konflikcie, w rozmowie z brytyjskim dyplomatą miał wyrazić obawy, iż Francuzi w niewystarczający sposób zaangażują się w działania przeciwko Karolowi VI. Jak twierdził wysłannik dworu św. Jakuba, Hiszpania była pełna podejrzliwości wobec Francji ${ }^{20}$. Dyplomacja francuska prowadziła rozmowy zarówno z Hiszpanią, jak i Sardynią. Już 26 września 1733 r. doszło do zawarcia paktu w Turynie między Francją a Sardynią rządzoną przez Karola Emanuela ${ }^{21}$. Kilkanaście dni później, w nocy z 12 na 13 października, francuskie oddziały przekroczyły Ren, co rozpoczęło działania wojenne ${ }^{22}$.

W kolejnych tygodniach na dworze hiszpańskim nasilały się nastroje antycesarskie. Głównym tematem rozmów była wojna, której wybuchu się spodziewano. Już 26 października siły hiszpańskie dotarły do Italii. Oddziały połączyły się pod Sieną, gdzie głównym dowódcą wojsk został mianowany don Carlos, mimo że fizycznie nie przebywał jeszcze $\mathrm{z}$ armią ${ }^{23}$. Iberyjskie państwo podjęło decyzję o zaangażowaniu się w konflikt jeszcze przed formalnym związaniem się sojuszem z sąsiadem zza Pirenejów. Jednak już 7 listopada 1733 r. Francja oraz Hiszpania podpisały traktat z El Escorial

16 J. Sutton, Wojna o sukcesje, s. 27-29.

${ }^{17}$ B. Keene do księcia Newcastle, 21 VIII 1733, NAK, SP 94, vol. CXVII [brak paginacji].

18 B. Keene do księcia Newcastle, 24 VIII 1733, NAK, SP 94, vol. CXVII.

19 B. Keene do księcia Newcastle, 21 VIII 1733, NAK, SP 94, vol. CXVII.

${ }^{20}$ B. Keene do księcia Newcastle, 14 IX 1733, NAK, SP 94, vol. CXVII.

${ }^{21}$ J. Sutton, Wojna o sukcesje, s. 69.

22 Ibidem, s. 78.

${ }^{23}$ W. Hargreaves-Mawdsley, Eighteenth-Century Spain 1700-1788: A Political, Diplomatic and Institutional History, London 1978, s. 70. 
zwany pierwszym paktem familijnym. Obie strony zobowiązywały się w nim do zachowania przyjaźni. Państwa udzielały sobie wzajemnych gwarancji terytorialnych, zarówno w Europie, jak i poza nią. Dodatkowo gwarantowano synowi Filipa V - Carlosowi Parmę, Piacenzę oraz sukcesję w Toskanii. Co istotne, w podpisanym dokumencie znalazła się wzmianka o udzieleniu sobie wsparcia w przypadku wrogości ze strony Anglii. Francja zobowiązywała się również do wywierania nacisku na Wielką Brytanię w celu oddania przez nią Gibraltaru Hiszpanii. Ponadto strony wyrażały swój sprzeciw wobec sankcji pragmatycznej, a zwłaszcza zawarciu przez Marię Teresę małżeństwa z księciem Lotaryngii. Związek ten miał zagrażać „bezpieczeństwu domu Burbonów oraz pokojowi w Europie". Wojna przeciwko Karolowi VI miała być prowadzona, dopóki nie zostanie zagwarantowane bezpieczeństwo posiadłościom syna Filipa $V^{24}$.

Kiedy kilka dni przed zawarciem owego porozumienia Keene rozmawiał z Patiño, ten zaprzeczył jakoby Hiszpania miała dołączyć do sojuszu Francji z Piemontem. Minister stwierdził również, że nie zna szczegółów porozumienia francusko-sardyńskiego; nie widział tegoż dokumentu w ostatecznym kształcie. Dyplomata starał się uzyskać odpis paktu familijnego, donosił również, że jest przekonany, że zarówno Sardynia, jak i Hiszpania są opłacane przez Francję, aby uczestniczyć w konflikcie. Kilka dni później Brytyjczyka zapewniano, iż Hiszpania nie podpisała żadnego traktatu, który byłby wymierzony w Anglię i zależy jej na zachowaniu dobrych stosunkóww. Wysłannik Albionu, rozważając kwestię faktycznego udziału iberyjskiego królestwa w konflikcie, słusznie przewidywał, że Hiszpanie nie dołączą do oblężenia Mediolanu, lecz wyruszą w stronę Neapolu i Sycyliii ${ }^{26}$. Oficerowie mający wyruszyć z żołnierzami zgromadzili się w Barcelonie, zaś powodem, dla którego pozostawali na miejscu miała być niesprzyjająca pogoda ${ }^{27}$. Jesienią $1733 \mathrm{r}$. Keene regularnie słał do Londynu depesze, w których opisywał stan przygotowań sił hiszpańskich, które miały zmierzać do Włoch ${ }^{28}$.

Na początku stycznia $1734 \mathrm{r}$. Keene donosił o rozpoczętym przez Hiszpanów marszu w stronę Neapolu. Przemarsz wojsk hiszpańskich we Włoszech okazał się sukcesem, zostali powitani na terenach, na które wkraczali z entuzjazmem ${ }^{29}$. Postępami hiszpańskimi byli zaskoczeni także Francuzi, którzy starali się nawet nieco spowolnić działania sojuszników w Italii. Ci jednak zdecydowali się wysłać dodatkowe posiłki drogą morską ${ }^{30}$. Francja oczekiwała zresztą zaangażowania się Hiszpanii w dolinie Padu,

${ }^{24}$ Treaty of El Escorial, between Spain and France, sometimes known as the First Family Pact. 7 November 1733, [w:] Spain under the Bourbons, 1700-1833. A collection of documents, ed. W. Hargreaves-Mawdsley, London 1973, s. 97-98.

25 B. Keene do księcia Newcastle, 7 XI 1733, NAK, SP 94, vol. CXVII.

${ }^{26}$ B. Keene do księcia Newcastle, 4 XI 1733, NAK, SP 94, vol. CXVII.

27 B. Keene do księcia Newcastle, 9 XI 1733, NAK, SP 94, vol. CXVII.

${ }^{28}$ Np. B. Keene do księcia Newcastle, 24 X 1733, NAK, SP 94, vol. CXVII.

29 W. Hargreaves-Mawdsley, Eighteenth-Century Spain, s. 70.

30 B. Keene do księcia Newcastle, 9 I 1734, NAK, SP 94, vol. CXIX. 
co jednak nie było w interesie syna Filipa V, którego głównym celem było zdobycie ziem, nad jakimi miał sprawować władzę.

Brytyjska dyplomacja, mimo wysłania do Italii przez państwo Filipa $V$ wojsk przeciw cesarzowi, starała się forsować rozwiązanie konfliktu w sposób pokojowy. Proponowano między innymi ślub don Carlosa z młodszą arcyksiężniczką. W prywatnych rozmowach Patiño miał odnosić się do takiego rozwiązania w miarę pozytywnie. W związku z tym Keene starał się dociekać, czy są prowadzone jakieś rozmowy w tej kwestii. Ambasador dostrzegał dwuznaczną postawę królowej Elżbiety Farnese, był przekonany, że jeżeli uda jej się doprowadzić do małżeństwa syna z Habsburżanką, to bez oporów zwróci się ona przeciwko Francji. Jak się jednak okazało, Hiszpanie zignorowali propozycję matrymonialną i nie odnieśli się do niej. Dlatego też w liście do księcia Newcastle z 9 stycznia Keene usprawiedliwiał się, dlaczego nie informował o postępach rozmów w tej sprawie ${ }^{31}$. Zdaniem brytyjskiego przedstawiciela powodem fiaska rozmów o małżeństwie habsbursko-burbońskim było zbyt długie zwlekanie ze strony Wiednia z odpowiedzą. Według Keene’a w sytuacji coraz większych postępów hiszpańskich na Półwyspie Apenińskim jakiekolwiek pomysły mariażu między dynastycznego są wykluczone. Mimo to, co jakiś czas na madryckim dworze pojawiały się doniesienia o możliwym aliansie. Już 11 stycznia dyplomata wysłał specjalną depeszę do księcia Newcastle, w której pisał o dostarczeniu Patiño anonimowego listu, wedle którego cesarz miał zgodzić się wydać swoją młodszą córkę za don Carlosa. Młoda para otrzymałaby większą część włoskich terytoriów Karola VI. W zamian zaś Hiszpania miała wycofać swe poparcie dla Francji. Mimo że wysłannik brytyjski zdecydował się wysłać specjalną korespondencję ze wzmianką o owym liście, to jak sam stwierdzał, nie wierzył w jego oryginalność. Patiño miał go zresztą poinformować, że dostał niejedną wiadomość o podobnej treści. Jak stwierdzał Keene, „są one wytworem próżniaczych umysłów, którym sprawia radość pisanie do publicznych osobistości” ${ }^{32}$. Pomysł ożenku jako sposobu na rozwiązanie konfliktu cesarsko-hiszpańskiego przedstawił również Robert Walpole, najważniejszy minister w brytyjskim rządzie. Habsburżanka miała wnieść w posagu Neapol oraz Sycylię, co zaspokoiłoby ambicję don Carlosa. Propozycję tę rozesłano do ambasadorów akredytowanych przy dworze brytyjskim - hiszpańskiego oraz austriackiego. Powodem, dla którego rozmowy w tej sprawie stanęły w miejscu miał być brak jasnych instrukcji dla wysłannika Karola VI - Kinsky’ego, który nie mógł przez to prowadzić rozmów w sprawie mariażu ${ }^{33}$.

Jak widać, nawet w momencie, gdy działania zbrojne przeciwko Karolowi VI rozgorzały, brytyjska dyplomacja starała się forsować pokojowe rozwiązanie i osiągnięcie

${ }^{31}$ B. Keene do księcia Newcastle, tajne, 9 I 1734, NAK, SP 94, vol. CXIX.

32 B. Keene do księcia Newcastle, 11 I 1734, NAK, SP 94, vol. CXIX.

${ }^{33}$ J. Hervey, Memoirs of the Reign of George the Second, from his Accession to the Death of Queen Caroline, vol. I, London 1848, s. 268-269. 
porozumienia między Habsburgiem a Hiszpanią. W swym liście z 9 stycznia Keene wyrażał nadzieję, że przekazane przez niego wieści pomogą rozstrzygnąć, czy cesarz nie zostanie nazbyt mocno osłabiony przez stratę swoich włoskich posiadłości i brak brytyjskiego zaangażowania w toczący się konflikt ${ }^{34}$. Dyplomaci na służbie Wielkiej Brytanii doskonale zdawali sobie sprawę z tego, że brak pomocy ze strony sojusznika jest ogromną stratą dla Karola VI i znacznie zmniejsza jego szanse w starciu z wrogami. Wiedziała o tym również doskonale Hiszpania i dlatego pilnie śledzono działania dyplomacji cesarskiej w Londynie. Na dwór hiszpański docierały wieści o intensywnych staraniach podejmowanych przez ambasadora cesarza w Londynie Philipa Kinsky'ego, który starał się nie dopuścić do ogłoszenia neutralności przez Wielką Brytanię $e^{35}$.

Dnia 13 stycznia do Hiszpanii dotarły informacje o kapitulacji Mediolanu przed siłami francusko-piemonckimi. Informacja ta wywołała zaskoczenie w Hiszpanii ${ }^{36}$. W liście z 1 lutego Keene donosił o przybyciu wojsk hiszpańskich w sile trzech tysięcy pod dowództwem księcia Lirii do Parmy, co nastąpiło 13 stycznia. W tej samej nocie brytyjski wysłannik donosił, iż książę wrócił już do głównego trzonu armii, który zmierza w stronę Neapolu ${ }^{37}$. Hiszpanie już na przełomie jesieni i zimy 1733 r. zabezpieczyli znajdującą się w ich władaniu Parmę, lecz wbrew nadziejom Francuzów, stacjonujące tam siły pod dowództwem markiza Montemar nie miały zostać wykorzystane do wspomożenia sojuszników ${ }^{38}$.

Warto w tym miejscu zauważyć, że Benjamin Keene, pełniąc swoją służbę, okazji do zdobycia informacji szukał nie tylko w trakcie spotkań z najważniejszymi osobistościami hiszpańskiego dworu, ale również składając wizyty innym ambasadorom znajdującym się w Madrycie. I tak 10 kwietnia odwiedził przedstawiciela Francji, który poinformował go między innymi o wsparciu udzielanemu Francji i Hiszpanii przez Sardynię, czy też wysłaniu do Italii 20 tys. żołnierzy francuskich ${ }^{39}$. Keene posiadał również zaufanego informatora na hiszpańskim dworze. To od niego otrzymywał wiele poufnych informacji. Dyplomata nazywał go w korespondencji wysyłanej do Londynu „przyjacielem” ${ }^{\prime 2}$. Ambasador brytyjski w Hiszpanii był również dość dobrze poinformowany o działaniach swoich kolegów po fachu w różnych zakątkach Europy. Regularnie otrzymywał informacje przekazywane przez innych ambasadorów i wysłanników, dlatego miał pełny obraz sytuacji na arenie międzynarodowej. Gdy nie posiadał wystarczających informacji dotyczących działań prowadzonych przez

\footnotetext{
34 B. Keene do księcia Newcastle, 9 I NAK, SP 94, vol. CXIX, część tajna.

35 B. Keene do księcia Newcastle, 9 I 1734, NAK, SP 94, vol. CXIX.

36 B. Keene do księcia Newcastle, 18 I 1734, NAK, SP 94, vol. CXIX.

37 B. Keene do księcia Newcastle, 1 II 1734, NAK, SP 94, vol. CXIX.

38 J. Sutton, Wojna o sukcesje, s. 88-99.

39 B. Keene do księcia Newcastle, 10 IV 1734, NAK, SP 94, vol. CXIX.

40 B. Keene do księcia Newcastle, 27 II 1734, NAK, SP 94, vol. CXIX.
} 
wysłanników brytyjskich w innych krajach, prosił o ich przesłanie. Tak było 1 lutego, kiedy zwrócił się o przekazanie wiadomości na temat wydarzeń w Wiedniu, gdyż jak stwierdzał, nie wie nic na ten temat ${ }^{41}$. Władze w Londynie aprobowały działania podejmowane przez przedstawiciela w Hiszpanii. Keene został pochwalony przez księcia Newcastle za sposób prowadzenia polityki na Półwyspie Iberyjskim ${ }^{42}$.

Wysłannik brytyjski przekazał sekretarzowi do spraw południowych informację o tym, że francuski ambasador jest zaskoczony i niezadowolony z tego, że cesarz cały czas trzyma swoje siły w Niemczech. Francja oczekiwała bowiem, że Karol VI wyśle wszystkie swoje siły do Italii, aby bronić tamtejszych ziem. Wówczas Bawaria miała ogłosić swój sojusz z Francją, o czym, co stwierdzał szyfrem, Keene został poinformowany ${ }^{43}$. Rzeczywiście, w Wiedniu rozważano wysłanie części sił z Nadrenii do Włoch, jednak uznano, że takie ich rozczłonkowanie w nadmierny sposób osłabi wojska stacjonujące w Cesarstwie, gdzie głównym zagrożeniem pozostawali Francuzi.

Tymczasem w Madrycie zimą 1734 r. obawiano się, że Wielka Brytania mogłaby wesprzeć cesarza poprzez atak na Hiszpanię od strony Gibraltaru. Wzmacniano także obronę od strony Galicji ${ }^{4}$. Hiszpanów niepokoiła również nadmierna aktywność brytyjskiej floty, którą również łączono z możliwością włączenia się Anglików w toczące się na kontynencie działania wojenne. Na wieść o nich książę Newcastle nakazał Keene'owi poważnie pomówić z Patiño i ostrzec go przed podejmowaniem działań, które mogłyby zagrozić bezpieczeństwu Gibraltaru ${ }^{45}$. Sekretarz stanu poinformował Keene’a, że prawdą jest, iż flota angielska została wzmocniona oraz znajduje się na morzu, a jednocześnie nie oznacza to, że zostanie wysłana, aby zaangażować się w konflikt. Sekretarza departamentu południowego zdumiało to, że minister Patiño dziwił się na działania podejmowane przez brytyjską flotę ${ }^{46}$.

$\mathrm{Na}$ hiszpańskim dworze pilnie śledzono również to, co dzieje się w parlamencie brytyjskim. Patiño w rozmowie z Keenem wyraził swoje niezadowolenie z przemowy Jerzego II. Minister obawiał się, że może być ona zwiastunem przyłączenia się Wielkiej Brytanii do wojny po stronie cesarza. Keene wyraził w odpowiedzi żal z powodu takiego, a nie innego odebrania słów swego monarchy. Zaznaczył, że nie jest upoważniony do dawania wykładni słów swego pana, lecz zwrócił uwagę na błąd w tłumaczeniu na język francuski przemowy brytyjskiego władcy ${ }^{47}$. Przemówienie Jerzego II

\footnotetext{
41 „I know nothing what is doing at Vienna”: B. Keene do księcia Newcastle, 1 II 1734, NAK, SP 94 , vol. CXIX.

42 B. Keene do księcia Newcastle, 29 III 1734, NAK, SP 94, vol. CXIX.

43 B. Keene do księcia Newcastle, 9 I 1734, NAK, SP 94, vol. CXIX.

44 B. Keene do księcia Newcastle, 25 I 1734, NAK, SP 94, vol. CXIX.

45 Książę Newcastle do Keene’a, 30 III 1734, NAK, SP 94, vol. CXXI.

46 B. Keene do księcia Newcastle, 7 II 1734, NAK, SP 94, vol. CXIX.

47 B. Keene do księcia Newcastle, 17 II 1734, NAK, SP 94, vol. CXIX.
} 
otwierające posiedzenie parlamentu 17 stycznia 1734 r. rzeczywiście nie wskazywało na chęć zaangażowania się Wielkiej Brytanii w wojnę. Król zaczął od zwrócenia uwagi parlamentarzystów na konflikt, który jest przedmiotem zainteresowania całej Europy. Jednocześnie władca zaznaczył, iż nie ma zamiaru włączać się weń, zaś celem rządzących jest przywrócenie pokoju na kontynencie i zadbanie o bezpieczeństwo poddanych brytyjskich $^{48}$. Reakcja hiszpańskiego ministra na wystąpienie króla w parlamencie pokazuje, że wysłannicy obcych mocarstw do Albionu zdawali sobie sprawę z wagi Westminsteru w polityce zagranicznej i niejednokrotnie tłumaczyli najważniejsze przemówienia bądź rezolucje Izby Gmin czy Izby Lordów ${ }^{49}$. Keene w liście z 27 lutego z satysfakcją stwierdzał, że chociaż Hiszpania i Francja wciąż żywią podejrzenia o możliwym zaangażowaniu się Wielkiej Brytanii w wojnę, to słowa monarchy nie dały im żadnego pretekstu do przygotowań, które zmusiłyby Albion do włączenia się w konflikt we własnym imieniu ${ }^{50}$.

Anglia, wbrew hiszpańskim obawom, nie planowała czynnie wspierać Karola VI. Jerzy II usprawiedliwiał się przed cesarzem, iż chciałby wesprzeć Habsburga, lecz nie jest to możliwe m.in. ze względu na trudności wewnętrzne, zbliżające się wybory do parlamentu ${ }^{51}$, ale też doznane przez Karola VI porażki. Dodatkowo Brytyjczycy uznali, że cesarz sam jest winien wybuchu wojny ze względu na swoje zaangażowanie w elekcje władcy Rzeczpospolitej, w związku z czym postawienia traktatu z $1731 \mathrm{r}$. nie obowiązują i Albion nie ma obowiązku udzielenia Karolowi VI pomocy ${ }^{52}$.

Zamiast udzielić wsparcia militarnego Albion, wraz z Niderlandami, postawił rozpocząć mediacje w sprawie zawarcia rozejmu przez walczące państwa. Widać więc na tym przykładzie angażowanie się Jerzego II w politykę zagraniczną Wielkiej Brytanii. Niderlandy, tak jak i Albion, nie chciały angażować się w jakikolwiek konflikt zbrojny. Już od jesieni 1733 r. rząd Zjednoczonych Prowincji starał się rozpocząć mediacje w sprawie zawarcia pokoju przez Francję i cesarza. Do mediacji, głównie z powodu starań Horace’ego Walpole’a - wysłannika Wielkiej Brytanii do Holandii, przyłączyła się również Anglia. Oficjalnie starania o zawarcie pokoju ze strony państw morskich rozpoczęły się w lutym 1734 r., kiedy w Paryżu i Wiedniu przedłożono memoranda w tej

48 Journal of the House of Lords, vol. XXIV, London 1830, s. 318-319.

49 J. Black, Parliament and Foreign policy in the Eighteenth Century, Cambridge 2004, s. 50-51.

50 B. Keene do księcia Newcastle, 27 II 1734, NAK, SP 94, vol. CXIX.

51 Wybory te były istotne, gdyż istniało prawdopodobieństwo, że większość utraci w nich stronnictwo wspierające Roberta Walpole’a, co wynikało m.in. z tak zwanego excise crisis, którego istotą były dążenia do wprowadzenia akcyzy na tytoń, co w 1733 r. wywołało duży sprzeciw w parlamencie. Por. C. Jones, The House of Lords and the excise crisis: The storm and the aftermath, 1733-5, "Parliamentary History” 2014, vol. XXXIII, No. 1, s. 160-200. https://doi.org/10.1111/1750-0206.12094

52 Ch. Backerra, Wien und London, 1727-1735. Internationale Beziehungen im fruben 18. Jahrbundert, Gottingen 2018, s. 104-105. https://doi.org/10.13109/9783666301940 
sprawie. Pomysł ten nie spodobał się głównie cesarzowi, który od sojusznika oczekiwał nie pomocy w mediacji, ale wsparcia militarnego ${ }^{53}$. Gdy pojawiły się pierwsze wieści dotyczące tego pomysłu, do Keene’a dotarła przesłana z Londynu informacja, iż Jerzy II nie sądzi, aby istniała potrzeba angażowania się w prowadzone rokowania Hiszpanii. Warto podkreślić, że ambasador otrzymał wiadomość, że opinię tę wyraził monarcha, została ona jako oficjalna przesłana wysłannikowi w Hiszpanii. Jednocześnie Keene miał odbyć rozmowę z Patiño i wybadać, czy ten chce już dążyć do zakończenia wojny ${ }^{54}$.

W Londynie istniało przekonanie, że „różnice” pomiędzy cesarzem a Hiszpanią mogą zostać rozstrzygnięte $\mathrm{w}$ innym traktacie niż tym ogólnie kończącym wojnę. Albion uznawał więc konflikt ten za mniej znaczący niż wojna między Karolem VI a Francją. Jednocześnie jednak szybko okazało się, iż starania brytyjskiej dyplomacji o sprawne zakończenie działań wojennych nie zostaną zrealizowane tak łatwo. Cesarz nie chciał nawet rozpoczynać negocjacji pokojowych, dopóki nie zostaną mu zwrócone zagarnięte ziemie ${ }^{55}$.

W korespondencji z 6 lutego Keene wysłał do Londynu dokumenty, które jego zdaniem były niezbędne, aby rząd brytyjski mógł wyrobić sobie pełen obraz wydarzeń rozgrywających się w Europie. Jak stwierdzał ambasador, będą przydatne niezależnie od tego, czy Albion pozostanie neutralny, czy też zdecyduje się wesprzeć cesarza w toczącym się konflikcie. Przesłane dokumenty dotyczyły planów zdobycia Neapolu, informacji o możliwym udzieleniu przez Bawarię wsparcia Francji, a także umieszczenia hiszpańskich dział przy granicy z Gibraltarem, aby przestraszyć Anglię. Dane dotyczyły również szczegółowych zamierzeń wspólnych działań francusko-hiszpańskich ${ }^{56}$. Zdobyte przez Keene’a pisma pokazywały między innymi, że Hiszpanie nie byli pewni, jakie kroki podejmą Brytyjczycy i czy zechcą się opowiedzieć po stronie Habsburga. Plany działań prewencyjnych w okolicach Gibraltaru pokazują, iż Hiszpania wciąż obawiała się militarnego zaangażowania Anglii w konflikt i chciała zminimalizować zagrożenie ze strony wyspiarskiego kraju. Keene pisał, że rozpoczęta kampania w Italii kosztowała skarb hiszpański już trzy miliony piastrów. Jak dodawał, tak kosztowna wojna mogła nie spotkać się z aprobatą kortezów, z czego musiał zdawać sobie sprawę również Patiño $0^{57}$.

Wiosną 1734 r. na hiszpańskim dworze zaczęto zastanawiać się nad możliwością rozstrzygnięcia konfliktu z cesarzem przy udziale angielskiej mediacji. Keene donosit, że kwestie dotyczące zakończenia wojny nie leżą jednak w gestii hiszpańskich decydentów, lecz Hiszpania pozostawała pod dużym wpływem Francji, do której należało

${ }^{53} \mathrm{H}$. Dunthorne, The maritime powers 1721-1740. A study of Anglo-Dutch relations in the age of Walpole, New York-London 1986, s. 290-291.

${ }^{4}$ Książę Newcastle do B. Keene’a, 13 I 1734, NAK, SP 94, vol. CXXI.

55 H. Dunthorne, The maritime powers, s. 275.

56 B. Keene do księcia Newcastle, 6 II 1734, NAK, SP 94, vol. CXIX.

57 B. Keene do księcia Newcastle, 17 II 1734, NAK, SP 94, vol. CXIX. 
ostatnie słowo w sprawie udziału królestwa z Półwyspu Iberyjskiego w wojnie. Zdaniem dyplomaty Patiño podejmie decyzje dotyczące dalszego postępowania Hiszpanii, gdy przekona się, jaki opór w Italii może stawić cesarz. Według brytyjskiego dyplomaty, jeśli armia we Włoszech będzie miała szanse wywalczyć władztwo dla don Carlosa, to minister będzie optował za wzmocnieniem sił na Półwyspie Apenińskim ${ }^{58}$. Do tego brytyjski wysłannik przekazał informacje o niechęci rządu hiszpańskiego do dołączenia do paktu zawartego w Turynie we wrześniu poprzedniego roku. Hiszpanie mieli złożyć wiele zastrzeżeń, o których nie wiedziała Sardynias9. Keene starał się więc przekonać Hiszpanów do pójścia na kompromis z cesarzem. Anglik przekonywał, że będzie to najlepsze rozwiązanie, gdyż hiszpańska armia jest oddzielona od francuskiej i sabaudzkiej. Dodatkowo podkreślano, iż cesarz ma zamiar podjąć działania odwetowe nad Renem oraz we Włoszech. Ambasador zwrócił uwagę Hiszpanów na to, że wcześniejsi sojusznicy mogą się od nich odwrócić. Tego typu zabiegi podejmował ze względu na polecenie, jakie otrzymał z Londynu. Keene miał podkreślać, że Francja i Sardynia nie są dla królestwa Filipa V najlepszym sojusznikiem, dodatkowo w przypadku udanej kontrofensywy cesarza, to don Carlos zostanie poświęcony przez sprzymierzeńców. W Londynie uważano, że królowa Elżbieta Farnese przez swą nadmierną ambicję przeszkodzi w rozważeniu przez hiszpańskich decydentów logicznych argumentów za wycofaniem się z wojny ${ }^{60}$. Książę Newcastle informował wysłannika brytyjskiego w Hiszpanii o tym, że Francuzi mieli zachęcać Hiszpanów do wystąpienia przeciwko Albionowi, lecz królestwo leżące na Półwyspie Iberyjskim odmówiło ${ }^{61}$.

Postępy armii hiszpańskiej sprawiały, że brytyjskie propozycje pokojowego rozwiązania sporu nie trafiły jednak na podatny grunt. Wiosną 1734 r. siły pod dowództwem syna Filipa V z sukcesami zdobywały kolejne twierdze i miasta we Włoszech. Keene słał do Londynu nie tylko informacje dotyczące hiszpańskich wojsk, które już znalazły się w Italii, ale śledził również przygotowania do wysłania przez morze kolejnych posiłków. Jak zauważał pod koniec marca, przygotowania te trwały, lecz były powolne. Brytyjczyk przypuszczał, że transport nie będzie gotowy przed początkiem maja ${ }^{62}$. Keene przesłał do Londynu tabelę przedstawiającą rozkład sił, jakimi Hiszpania dysponowała we Włoszech ${ }^{63}$. Do korespondencji dyplomatycznej Brytyjczyk dołączył również manifest wydany przez don Carlosa skierowany do mieszkańców królestwa Neapolu wraz z tłumaczeniem na angielski ${ }^{64}$.

58 B. Keene do księcia Newcastle, 13 III 1734, NAK, SP 94, vol. CXIX.

59 B. Keene do księcia Newcastle, 22 III 1734, NAK, SP 94, vol. CXIX.

${ }^{60}$ Książę Newcastle do B. Keene’a, 29 III 1734, NAK, SP 94, vol. CXIX.

${ }^{61}$ Książę Newcastle do B. Keene’a, 29 III 1734, NAK, SP 94, vol. CXIX.

62 B. Keene do księcia Newcastle, 31 III 1734, NAK, SP 94, vol. CXIX.

63 State of the Spanish army, 7 IV 1734, NAK, SP 94, vol. CXIX.

${ }^{64}$ Don Carlos Declarations to the Neapolitans, Don Carlos Declarations to the Neapolitans \& Sicilians translation, NAK, SP 94, vol. CXIX. 
Na marginesie spraw związanych z działaniami wojennymi znalazła się kwestia małżeństwa córki Jerzego II. W marcu 1734 r. Keene miał za zadanie oficjalnie poinformować Filipa V o planowanym ślubie córki Jerzego I Anny z Wilhelmem IV księciem Oranii ${ }^{65}$. Dostarczenie tej radosnej nowiny zostało jednak zakłócone przez pewien zgrzyt dyplomatyczny. Otóż z powodu pominięcia w tytulaturze hiszpańskiego monarchy określenia utriusque Sicilia Regi odwołano audiencję zaplanowaną dla Keene’a. Dyplomata tłumaczył, że po określeniu Regi Catolico pominął również inne tytuły, co też czyni się przy publicznych okazjach. Takie wyjaśnienie nie usatysfakcjonowało jednak dostojników na dworze. Keene wyjaśniał więc, że tytuł ten pominięto na przestrzeni ostatnich lat kilkukrotnie i nigdy dwór hiszpański nie protestował ${ }^{66}$. Brytyjski dyplomata wysłał do Londynu kopię listu, jaki przesłał do Patiño ${ }^{67}$. Można się zastanawiać, czy nagłe uwrażliwienie dworu hiszpańskiego na kwestie prawidłowej tytulatury nie wynikało z toczącego się właśnie konfliktu w Italii i chęci podkreślenia swych praw do ziem we Włoszech. O całej sprawie 31 maja Keene pisał również do Williama Stanhope’a hrabiego Harrington, który pełnił funkcję sekretarza stanu departamentu północnego, a wcześniej był wieloletnim wysłannikiem Albionu w Hiszpanii ${ }^{68}$.

W królestwie Filipa V zdawano sobie sprawę z tego, że głównym celem brytyjskiej polityki zagranicznej jest zachowanie równowagi sił. W trakcie rozmowy Keene’a z Patiño z 16 maja hiszpański minister relacjonował, iż otrzymał wiadomość o rozmowie przeprowadzonej przez wysłannika korony Hiszpanii do Wielkiej Brytanii w Londynie. Jak pisał wysłannik Albionu, jego odpowiednik w Londynie

\begin{abstract}
he was asked whether the conquest were made in the Infant's name, or whether they were to be reunited to the Spanish monarchy, a point very material to England, who was so much concerned in the Balance of Power in Europe. He [Patiño - M.M.] told me the ambassador did not know well how to reply, but he hoped I had given Your Grace an account of our conversations on this subject, and he repeated his former assurances that Spain would gain nothing for itself in the present troubles ${ }^{69}$.
\end{abstract}

Jak widać, Hiszpania chciała zapewnić władze w Londynie, iż jej udział w toczącej się wojnie nie stoi w sprzeczności z interesami Albionu. Co więcej, przedstawiano

65 Małżeństwo to planowano od wiosny 1733 r., do jego zawarcia doszło 14 III 1734 r. Por. M. Kilburn, Anne, Princess Royal, [w:] ODNB, https://www.oxforddnb.com/view/10.1093/ref:odnb/ 9780198614128.001.0001/odnb-9780198614128-e-68369?rskey=RIB2Mq\&result=2 (dostęp 26.10.2020).

66 B. Keene do księcia Newcastle, 21 IV 1734, NAK, SP 94, vol. CXIX.

67 B. Keene do księcia Newcastle, tajne, 21 IV 1734, NAK, SP 94, vol. CXIX.

68 B. Keene do Harringtona, 31 V 1734, NAK, SP 94, vol. CXIX; P. Woodfine, Stanhope, William, first earl of Harrington, [w:] $O D N B$, https://www.oxforddnb.com/view/10.1093/ref:odnb/ 9780198614128.001.0001/odnb-9780198614128-e-26257?rskey=Y87KKX\&result=2 (dostęp 26.10.2020).

69 B. Keene do księcia Newcastle, 17 V 1734, NAK, SP 94, vol. CXIX. 
zaangażowanie się w wojnę na terenie Włoch jako wyprawę, której jedynym celem jest zagwarantowanie dziedzictwa dla młodszego syna Filipa V.

Keene, obserwując sytuację na hiszpańskim dworze, stwierdzał, że cesarz powinien rozpocząć rozmowy o zawieszeniu broni z Hiszpanią, nie oglądając się na Francję i Sardynię. Jak zauważał brytyjski wysłannik, Karol VI „has a Door open for such a negociation"70. Chęć rozpoczęcia negocjacji była tym bardziej prawdopodobna, że w maju 1734 r. Hiszpania mogła prowadzić je z pozycji państwa zwyciężającego wojnę. Do Madrytu napływały coraz to nowe informacje o sukcesach na froncie w Italii i bliskim wkroczeniu don Carlosa do Neapolu. W drugiej połowie maja wysłano też z Barcelony kolejne posiłki w sile pięciu batalionów oraz dwóch tysięcy konnych $^{71}$. Już 9 maja poddał się Neapol, a dzień później młody Burbon został ogłoszony królem Neapolu ${ }^{72}$. Mimo sukcesów infanta Hiszpanie nie spieszyli się z oficjalnym uznaniem tegoż tytułu. Patiño chciał traktować go jako króla de facto, bez formułowania jednoznacznych hiszpańskich deklaracji na ten temat ${ }^{73}$. Jednak na początku czerwca Hiszpanie wiadomość o zdobyciu przez don Carlosa Neapolu potraktowali z nieskrywanym entuzjazmem. W madryckich kościołach z tej okazji odśpiewano Te Deum ${ }^{74}$.

Mimo sukcesów, Patiño pilnie śledził negocjacje pokojowe w Hadze. W lipcu Keene odbył rozmowę dotyczącą kwestii związanych z możliwymi rokowaniami. Wyjaśnił hiszpańskiemu ministrowi m.in., dlaczego Wielka Brytania zwróciła się z tą sprawą najpierw do Francji. W kwestii tej współpracował ściśle z ambasadorem niderlandz$\mathrm{kim}^{75}$. W tajnym liście do księcia Newcastle Keene pisał o warunkach, jakie Hiszpanie stawiają przed przystąpieniem do rozmów pokojowych. Wysłannik Albionu donosił również, że Patiño oraz Filip V deklarują chęć zakończenia wojny. Hiszpański minister zapewniał Keene’a, że jeśli cesarz zaakceptuje mediację Wielkiej Brytanii oraz Niderlandów, to Hiszpania uczyni to samo. Anglik zwracał uwagę księcia Newcastle na fakt, iż Francja nie informowała sojusznika o podejmowanych przez siebie działaniach ${ }^{76}$.

Pomimo starań o podjęcie rozmów pokojowych, działania wojenne w Italii nie ustawały. Keene regularnie przesyłał do Londynu wiadomości, jakie docierały na dwór Filipa V. Pisał chociażby o sporze, który podobno pojawił się pomiędzy dowódcami Karola VI, hrabią Mercy oraz księciem Wirtemberskim. Mieli oni nie móc dojść do

\footnotetext{
70 B. Keene do księcia Newcastle, 17 V 1734, NAK, SP 94, vol. CXIX.

71 B. Keene do księcia Newcastle, 24 V 1734, NAK, SP 94, vol. CXIX.

${ }^{72}$ H. Kamen, Philip V of Spain, s. 195.

73 B. Keene do księcia Newcastle, 31 V 1734, NAK, SP 94, vol. CXIX.

74 B. Keene do księcia Newcastle, 14 VI 1734, NAK, SP 94, vol. CXIX.

75 B. Keene do księcia Newcastle, 5 VII 1734, NAK, SP 94, vol. CXX.

76 B. Keene do księcia Newcastle, 3 VII 1734, NAK, SP 94, vol. CXX.
} 
porozumienia, czy wydać walną bitwę armii francuskiej, czy też nie. W związku z tym wysłali do Wiednia posłańca, aby poznać opinię cesarza w tej sprawie. Dalszych działań nie podejmowali również Sardyńczycy, co przedstawiciel tego kraju w Hiszpanii tłumaczył potrzebą zabezpieczenia własnych terytoriów ${ }^{77}$.

W sierpniu zainteresowanie brytyjskiego dyplomaty wzbudziło to, że w armii hiszpańskiej miał służyć jeden z synów pretendenta do tronu Wielkiej Brytanii ze strony Stuartów. Chodziło tu o Karola Edwarda Stuarta, zaledwie czternastoletniego, który towarzyszył armii pod dowództwem księcia Lirii ${ }^{78}$. Sprawę tę zamierzał wyjaśnić osobiście z Patiño, przypuszczając, że na służbę tak ważnej osoby minister musiał wyrazić zgodę osobiście. Hiszpan miał wyrazić zdziwienie sytuacją, o której ponoć nie wiedział. Zobowiązał się jednak wobec brytyjskiego dyplomaty sprawę wyjaśnićn ${ }^{79}$. Wkrótce poinformował, że wysłał do księcia Liria rozkaz nakazujący mu odesłanie syna pretendenta do Rzymu ${ }^{80}$. Aby nie psuć relacji z Wielką Brytanią, hiszpański dowódca odesłał więc Karola Edwarda Stuarta ${ }^{81}$. Warto w tym miejscu zauważyć, że w historiografii brytyjskiej często podkreśla się, że jedną z przyczyn niezaangażowania się Albionu w wojnę o sukcesję polską była właśnie obawa przed jakobickim zagrożeniem $^{82}$. Jak widać, postawa brytyjska skutkowała tym, iż książę z rodu Stuartów został szybko usunięty z hiszpańskiej armii, a jednocześnie Anglicy zostali zapewnieni o braku złych chęci ze strony osób, które pozwoliły młodemu synowi pretendenta uczestniczyć w kampanii.

W Hiszpanii, rozważając dążenie do zakończenia konfliktu, zdawano sobie sprawę, iż niezbędnym warunkiem zawieszenia broni będzie zagwarantowanie dziedzictwa dla syna królowej. Wiedziano również, że wojna tocząca się we Włoszech nie ma żadnego powiązania ze sporem, jaki ma miejsce w Polsce i brakiem porozumienia w kwestii tego, kto zostanie władcą Rzeczypospolitej. Dlatego też po raz kolejny brano pod uwagę możliwość zawarcia osobnego pokoju między Hiszpanią a cesarzem ${ }^{83}$. Keene był przekonywany przez Hiszpanów, że Patiño pragnie dążyć do pokoju i namawia do tego króla ${ }^{84}$. Jednocześnie minister zmierzał do ustanowienia trwałej władzy don Carlosa w Italii, dlatego też zależało mu, aby w jego rękach znalazło się po zakończeniu wojny jak

77 B. Keene do księcia Newcastle, 12 VII 1734, NAK, SP 94, vol. CXX.

78 M.G.H. Pittock, Charles Edward [Charles Edward Stuart; styled Charles; known as the Young Pretender, Bonnie Prince Charlie], [w:] ODNB, https://www.oxforddnb.com/view/10.1093/ref:odnb/ 9780198614128.001.0001/odnb-9780198614128-e-5145?rskey=kyYySX\&result=1 (dostęp 26.10.2020).

79 B. Keene do księcia Newcastle, 20 VIII 1734, NAK, SP 94, vol. CXX.

80 B. Keene do księcia Newcastle, 21 VIII 1734, NAK, SP 94, vol. CXX.

${ }^{81}$ Minute of a Letter written on the $20^{\text {th }}$ aug. to Count Santisteran in answer to another of his of $3^{\text {th }}$ of the same month, relating to the Cher. Dest. George the younger, NAK, SP 94, vol. CXX.

82 J. Black, English neutrality, s. 359.

83 B. Keene do księcia Newcastle, 13 IX 1734, NAK, SP 94, vol. CXX.

${ }^{84}$ B. Keene do księcia Newcastle, 6 XI 1734, NAK, SP 94, vol. CXX. 
najmniej terenów spornych ${ }^{85}$. Hiszpański minister proponował, aby negocjacje pokojowe zostały zaproponowane Karolowi VI przez wysłannika brytyjskiego Robinsona i właśnie przy współudziale Wielkiej Brytanii miały, zdaniem Patiño, toczyć się rozmowy. Keene sugerował, że pomysł ten jest niepraktyczny, chociażby z tego względu, iż korespondencja dotycząca warunków pokoju musiałaby być przekazywana za pośrednictwem Londynu. Hiszpański minister mimo tej argumentacji nadal był przekonany do swego zamysłu, sądząc, że Brytyjczycy wiedzą, do czego w wojnie dążą obie strony. Jednym z powodów, dla których Hiszpania zmierzała do zawarcia separatystycznego pokoju, miała być niechęć względem Sardynii. Angielski ambasador prosił zaś w połowie listopada o instrukcje, w jaki sposób zachować się w obliczu dynamicznego rozwoju sytuacji na dworze ${ }^{86}$. Uzyskane informacje dotyczące chęci zawarcia osobnego pokoju z cesarzem przez Hiszpanię Keene przekazał również Horace’owi Walpole’owi. Pisał mu także o minimalnych żądaniach, jakie jego zdaniem przedstawi Hiszpania. Miały to być małżeństwo don Carlosa z arcyksiężniczką, królestwo Neapolu oraz Sycylii, część Toskanii i Lombardii ${ }^{87}$. Związek młodego Burbona oraz Habsburżanki Patiño uważał za gwarancję postanowień terytorialnych oraz ziem, jakie miały przypaść synowi Filipa $\mathrm{V}^{88}$.

Keene przesłał do Londynu przekazany Hiszpanom przez Francuzów projekt warunków zakończenia wojny stworzony przez Anglików. Postulaty w nim przedstawione były całkowicie niekorzystne dla Francji. Do Karola VI miała wrócić Parma, Toskania oraz Neapol. Francuzi mieli oddać wszystkie tereny zagarnięte nad Renem, brakowało również odniesienia uwzględniającego francuskie dążenia w Polsce. Dodatkowo Walpole miał przekonać Stany Generalne do zerwania neutralności z Francją. Do tego Anglicy mieli dążyć do zerwania przymierza łączącego Francję i Hiszpanię. Warto zwrócić uwagę na to, iż projekt ów uwzględniał pretensje don Carlosa do Neapolu oraz Sycylii, zaś głównym przegranym wojny miała zostać Francja. Przedstawiony projekt, do którego Keene dotarł w drugiej połowie listopada datowany był na lipiec. Francuzi, aby przeciwstawić się brytyjskim pomysłom, radzili Hiszpanii zacieśnienie więzów i harmonijną współpracę ${ }^{89}$. Na przełomie roku 1734 i 1735 brytyjski ambasador donosił o naciskach, jakie na Patiño wywierał ambasador francuski, aby wysłać zgromadzone siły do Italii ${ }^{90}$. W styczniu 1735 r. wojska hiszpańskie odniosły kolejny sukces i zdobyły Sycylię, do której triumfalnie wkroczył don Carlos ${ }^{91}$.

\footnotetext{
${ }^{85}$ B. Keene do księcia Newcastle, 15 XI 1734, NAK, SP 94, vol. CXX.

${ }^{86}$ Ibidem.

${ }^{87}$ B. Keene kopia listu do Horace Walpole'a, 15 XI 1734, NAK, SP 94, vol. CXX.

${ }^{88}$ B. Keene do księcia Newcastle, 27 XI 1734, NAK, SP 94, vol. CXX.

${ }^{89}$ Extract of a Paper from the Garde des Suaux dated 27. July, transmitted by Mr de la Baume on the $3^{\text {rd }}$ August, and communicated by him to Mo. Patiño, NAK, SP 94, vol. CXX.

90 B. Keene do księcia Newcastle, 3 I 1735, NAK, SP 94, vol. CXXII.

91 W. Hargreaves-Mawdsley, Eighteenth Century, s. 70.
} 
W sprawie rozmów pokojowych Keene ściśle współpracował z niderlandzkim wysłannikiem. Niejednokrotnie wraz z nim rozmawiał z hiszpańskim ministrem, dowiadywał się również od kolegi po fachu, jakie informacje ten zdobywał w trakcie spotkań z Patiño. Taka współpraca pozwalała angielskiemu przedstawicielowi na lepsze zrozumienie hiszpańskiego punktu widzenia. Tymczasem w początkach 1735 r. Patiño narzekał na to, iż cesarz nie dostatecznie jasno wyraża swoje opinie. Hiszpański minister oczekiwał, że Karol VI precyzyjnie określi swoje żądania, aby można się było do nich odnieśćc ${ }^{92}$. Jednocześnie dla Keene’a oczywistym było, że królowa i Patiño chcą zakończyć wojnę. Jednakże dla Elżbiety Farnese ważną kwestią pozostawało wynegocjowanie korzystnego ożenku dla syna. Jak stwierdzał brytyjski wysłannik, jeśli nie uda jej się doprowadzić do ślubu potomka z arcyksiężniczką, to jego matka będzie się starała uzyskać rękę księżniczki Lotaryńskiej³. Negocjacje pokojowe, w których oprócz Hiszpanii uczestniczyła Francja nie zmierzały jednak ku końcowi, albowiem kardynał Fleury nie miał zamiaru korzystać z pomocy państw morskich przy rozstrzygnięciu konfliktu, a jedynie chciał mieć pewność, że Niderlandy i Wielka Brytania nie podejmą żadnych działań w obronie cesarza ${ }^{94}$.

W lutym 1735 r. Keene otrzymał z Londynu informacje dotyczące poglądów cesarza na zawarcie osobnego pokoju z Hiszpanią. Karol VI miał być nastawiony do takiego pomysłu pozytywnie. Jednocześnie nie chciał podać własnych warunków, dopóki nie będzie wiedział, co usatysfakcjonuje jego przeciwnika ${ }^{95}$. W tym samym czasie książę Newcastle informował dyplomatę, że Jerzy II chciał zatrudnić 30 tys. marynarzy, aby wywrzeć nacisk na państwa uczestniczące w toczącym się w Europie konflikcie. Propozycja ta została przedstawiona w Izbie $\mathrm{Gmin}^{96}$, co pokazuje, że Wielka Brytania chciała wywierać większą presję na walczące państwa, by doszły do porozumienia. Tymczasem kwestia prowadzonych przez potęgi morskie negocjacji pokojowych wywołała w marcu 1735 r. pewne niezadowolenie na dworze hiszpańskim. Keene donosit, że panuje przekonanie, iż Niderlandy i Wielka Brytania chcą ustanowić się arbitrem Europy, zamiast jej mediatorem. Również francuski ambasador wyrażał niezadowolenie z przedstawionych w Hadze propozycji ${ }^{97}$. Brytyjski dyplomata ponownie podkreślał, że kluczem do zdobycia poparcia królowej oraz Patiño jest zagwarantowanie nienaruszalności władania don Carlosa. Bez tego żadna propozycja przedstawiona przez Albion nie zdobędzie uznania na hiszpańskim dworze ${ }^{98}$. Dnia 18 lutego 1735 r. książę Newcastle

\footnotetext{
${ }^{22}$ B. Keene do księcia Newcastle, 10 I 1735, NAK, SP 94, vol. CXXII.

${ }_{93}$ B. Keene do księcia Newcastle, 14 I 1735, NAK, SP 94, vol. CXXII.

${ }_{94}$ R. Lodge, English neutrality, s. 162-163.

${ }^{9}$ Książę Newcastle do B. Keene’a, 12 II 1735, NAK, SP 94, vol. CXXIV.

${ }_{96}$ Ibidem.

${ }^{97}$ B. Keene do księcia Newcastle, 7 III 1735, NAK, SP 94, vol. CXXIV.

98 Ibidem.
} 
poinformował Keene’a o przesłaniu do ambasadora hiszpańskiego planu akomodacyjnego. Jednocześnie wysłał projekt wysłannikowi Wielkiej Brytanii. Sekretarz stanu donosił również, że taki sam dokument otrzyma od swego rządu ambasador niderlandzki, dlatego obaj mogą ze sobą ściśle współpracować przy forsowaniu planu na hiszpańskim dworze" ${ }^{99}$. Newcastle spodziewał się, że Hiszpania może nie chcieć zaakceptować przedstawionych warunków, dlatego też sądził, iż należy przekonać Filipa V oraz Patiño, że rozpoczęli niesprawiedliwą wojnę i błędem było atakowanie cesarza. Polityk chciał, by wysłannik Albionu mocno akcentował współpracę brytyjsko-niderlandzką, a także ryzyko poniesienia przez Hiszpanię konsekwencji w przypadku odrzucenia planu. Księciu Newcastle zależało również na tym, aby plan został przyjęty jak najszybciej, zanim wznowione zostaną działania wojenne. Jednocześnie zdawał sobie sprawę, że utrata Neapolu i Sycylii może zostać ciężko przyjęta przez cesarza ${ }^{100}$. Keene 22 marca donosił o tym, że wysłannik niderlandzki dostarczył projekt tzw. planu akomodacji, który miał zostać zawarty przez wszystkie walczące strony. W jego ramach mieściło się m.in. uznanie Stanisława Leszczyńskiego za króla Polski; chociaż miał on abdykować, cesarz miał otrzymać Parmę, Piacenzę i Toskanię ${ }^{101}$. Wielkiej Brytanii zależało przy tym, aby doszło do zawieszenia broni na czas prowadzonych negocjacji. Patiño stwierdzał jednak, że kwestia przerwania wojny nie jest zbyt prosta i nie zależy tylko od dobrej woli dworu hiszpańskiego. Keene w rozmowie z hiszpańskim ministrem wyraził zdziwienie, przypominając zapewnienia, jakich wcześniej miał okazję wysłuchiwać, dotyczące niezależności Hiszpanii od jej sojuszników ${ }^{102}$.

Pod koniec marca hiszpański minister nie krył swego niezadowolenia z faktu, iż projekt przedstawiony Hiszpanom jest powszechnie znany w Wielkiej Brytanii i ukazał się w druku. Minister uważał, że jest to forma wywierania presji na Hiszpanię, aby zgodziła się na przedstawione warunki ${ }^{103}$. W angielskiej prasie w drugiej połowie marca rzeczywiście pojawily się publikacje dotyczące projektowanego pokoju ${ }^{104}$. W początkach kwietnia książę Newcastle przekazał wysłannikowi w Hiszpanii informację o rozczarowaniu Jerzego II brakiem entuzjazmu ze strony hiszpańskich decydentów wobec planu, który gwarantował zachowanie panowania don Carlosa w Neapolu i Sycyliii ${ }^{105}$. W kwietniu Keene pisał, że Hiszpanie uzależniają swoje stanowiska od decyzji i obiekcji

99 Książę Newcastle do B. Keene’a, 18 II 1735, NAK, SP 94, vol. CXXIV.

100 Książę Newcastle do B. Keene’a, 24 II 1735, NAK, SP 94, vol. CXXIV.

101 Plan został opracowany w ścisłej współpracy z kardynałem Fleurym, lecz zależało mu na tym, aby cesarz oraz Hiszpania uważały niniejsze propozycje za efekt mediacji państw morskich. Por. J. Sutton, Wojna o sukcesje, s. 191-193.

102 B. Keene do księcia Newcastle, 22 III 1735, NAK, SP 94, vol. CXXII.

${ }^{103}$ B. Keene do księcia Newcastle, 28 III 1735, NAK, SP 94, vol. CXXII.

${ }^{104}$ Por. „The Daily Journal”, 19 III 1735, No. 4429.

105 Książę Newcastle do B. Keene’a, 3 III 1735, NAK, SP 94, vol. CXXIV. 
francuskich. Jednocześnie, obserwując sytuację militarną we Włoszech, brytyjski wysłannik stwierdzał, że siły cesarskie nie będą podejmować działań ofensywnych mających na celu odzyskanie zajętych przez inne państwa terytoriów, lecz będą dążyć do obrony terenów wciąż znajdujących się we władaniu Karola VI ${ }^{106}$. Dyplomacja brytyjska przez cały kwiecień i początek maja czekała na odpowiedź dworu hiszpańskiego na przedstawiony plan ${ }^{107}$.

Warto zauważyć, że ze względu na podróż króla do Hanoweru wiosną i latem 1735 r. Keene listy dotyczące sytuacji na dworze hiszpańskim kierował nie tylko do księcia Newcastle, ale również do Harringtona, który udał się na kontynent wraz z monarchą ${ }^{108}$. Tymczasem sekretarz stanu do spraw południowych korespondencję, która docierała do Londynu przedkładał królowej Karolinie, pełniącej funkcję regentki na czas nieobecności męża ${ }^{109}$. Żona Jerzego II aprobowała działania prowadzone przez Keene’a ${ }^{110}$. W sierpniu 1735 r. dyplomata w rozmowie z Patiño poruszył temat tego, czy rozwój wydarzeń w Polsce wpłynie na zawarcie przez Hiszpanię pokoju z cesarzem, skoro ta osiągnęła sukces we Włoszech. Minister stwierdził, że kwestia działań w Rzeczypospolitej nie ma wpływu na relacje Hiszpanii z Karolem VI, co też zostało na początku wojny ustalone z Francją ${ }^{111}$. Wyraźnie widać, że Wielka Brytania wiosną oraz latem 1735 r. skupiła się na forsowaniu zawarcia pokoju między cesarzem oraz Hiszpanią już bez udziału Francji. Było to naturalne, gdyż od sierpnia tego samego roku Francuzi oraz Karol VI prowadzili tajne negocjacje bez udziału państw morskich ${ }^{112}$.

W dniu 3 października 1735 r. Francja i cesarz podpisali w Wiedniu preliminarze pokojowe. Na ich mocy Stanisław Leszczyński mógł mienić się władcą Rzeczypospolitej, a za utracone ziemie otrzymał rekompensatę w postaci Lotaryngii, która po jego śmierci miała zostać włączona do Francji. Dotychczasowy książę lotaryński Franciszek miał otrzymać jako rekompensatę Parmę, Piacenzę oraz Toskanię, dotychczas mające należeć do Burbonów hiszpańskich. Zamiast tego don Carlos miał otrzymać Neapol oraz Sycylię ${ }^{113}$. Dopiero 1 grudnia ambasador francuski poinformował o tym dwór hiszpański. Podpisanie porozumienia między cesarzem a Francją wywołało pewne zmieszanie w państwie Filipa $\mathrm{V}^{114}$. W wyniku tego traktatu Karol VI miał otrzymać

\footnotetext{
106 B. Keene do księcia Newcastle, 11 IV 1735, NAK, SP 94, vol. CXXII.

107 B. Keene do księcia Newcastle, 2 V 1735, NAK, SP 94, vol. CXXII.

108 W przypadku podróży władcy do Hanoweru w podróż z nim udawał się jeden z sekretarzy stanu, podczas gdy drugi pozostawał w Wielkiej Brytanii. Por. Introduction, [w:] Office-Holders in Modern Britain, vol. II (Officials of the Secretaries of State 1660-1782), ed. J.C. Sainty, London 1973, s. 1-21.

109 Książę Newcastle do B. Keene'a, 18 VII 1735, NAK, SP 94, vol. CXXIV.

110 Książę Newcastle do B. Keene'a, 18 IX 1735, NAK, SP 94, vol. CXXIV.

111 B. Keene do księcia Newcastle, 2 VIII 1735, NAK, SP 94, vol. CXXIII.

112 H. Dunthorne, The maritime powers, s. 295-297.

113 J. Sutton, Wojna o sukcesję, s. 201.

114 W. Hargreaves-Mawdsley, Eighteenth Century, s. 72.
} 
we Włoszech Parmę i Piacenzę, tereny na które Wielka Brytania udzieliła w 1731 r. gwarancji don Carlosowi. Książę Newcastle kazał Keene’owi wytłumaczyć złamanie owych gwarancji tym, iż Albion udzielił ich również cesarzowi na Neapol i Sycylię, które to Hiszpania zdobyła siłą. Dodatkowo brytyjski wysłannik miał przypomnieć Patiño, że Anglia robiła wszystko, aby zniechęcić Hiszpanię do udziału w wojnie, a następnie ułatwić jej wycofanie się $z$ niej ${ }^{115}$.

Zakończenie wojny między Hiszpanią a cesarzem obyło się bez udziału Wielkiej Brytanii. Karol VI 30 stycznia 1736 r. zadeklarował, że pozostaje w stanie pokoju z Hiszpanią. Tego samego dnia został zawarty kontrakt małżeński pomiędzy Franciszkiem Lotaryńskim a córką cesarza Marią Teresą ${ }^{116}$. W następnym miesiącu doszło do podpisania preliminarzy pokojowych między Hiszpanią a Habsburgiem. Pokój kończący konflikt cesarza i Hiszpanii został podpisany jednak dopiero 31 kwietnia 1739 r.

\section{$* * *$}

Korespondencja dyplomatyczna kierowana przez i do wysłannika w Wielkiej Brytanii pokazuje, że pomimo niepodjęcia działań militarnych mających na celu obronę interesu Karola VI, Albion czynił pewne starania, które mogły poprawić sytuację cesarza. Brytyjscy politycy chcieli rozstrzygnąć konflikt drogą pokojowych negocjacji. Od początku optowali za przekonaniem hiszpańskich polityków do rozwiązania konfliktu drogą pokojową, sugerowali również zawarcie związku małżeństwa między synem Filipa V a córką Habsburga. Dyplomacja brytyjska zdawała sobie sprawę z wpływu francuskiego, pod jakim miała pozostawać Hiszpania. Jednocześnie dostrzegano nieufność na dworze hiszpańskim wobec sojusznika oraz chęć dążenia do zagwarantowania bezpiecznego panowania don Carlosa we Włoszech, co było priorytetem dla państwa pod panowaniem Filipa V w toczącym się konflikcie. Dyplomacja angielska skupiała się głównie na jak najszybszym zakończeniu sporu. Czyniono usilne starania, aby Hiszpania zrezygnowała ze swojego uczestnictwa w wojnie. Wręcz do znudzenia brytyjski dyplomata usiłował forsować pomysł separatystycznego pokoju zawartego między cesarzem a państwem na Półwyspie Apenińskim. Jednocześnie hiszpańscy politycy pozostawali pod znacznie większym wpływem Francji niż Albionu, dlatego też starania te były bezowocne. Mimo podejmowania wielu prób, Benjamin Keene nie był w stanie prowadzić efektownej polityki w kraju, do którego został wysłany. Uniemożliwiały mu to podstawowe założenia brytyjskiej dyplomacji.

Wycofanie się Wielkiej Brytanii z konfliktu sprawiło, że nie miała decydującego wpływu na rozwój wydarzeń. Starania brytyjskiej dyplomacji mające na celu

\footnotetext{
115 Książę Newcastle do B. Keene'a, 27 XI 1735, NAK, SP 94, vol. CXXIII.

116 W. Hargreaves-Mawdsley, Eighteenth Century, s. 72.
} 
wycofanie się Hiszpanii z konfliktu również zakończyły się fiaskiem. Kraj ten zaprzestał prowadzenia działań wojennych dopiero wtedy, gdy zdobył tereny w Italii, na których najbardziej mu zależało oraz został porzucony w konflikcie przez Francję. Albion w roku 1733 był państwem, z którego siłą zarówno Francja, jak i Hiszpania liczyły się i obawiały jego zaangażowania się w spór po stronie cesarza. Przez cały okres wojny Patiño starał się nie doprowadzić do sytuacji, w której bezpośrednio zagroziłby Albionowi. Wielka Brytania starała się okazać lojalność względem cesarza poprzez próbę doprowadzenia do pokoju. Jednocześnie jednak politycy brytyjscy byli świadomi tego, że ich zaangażowanie wzmocniłoby siły Karola VI i uniemożliwiło sprzymierzonym państwom odniesienie tak spektakularnego sukcesu na Półwyspie Apenińskim. Neutralność wyspiarskiego kraju w dalszej perspektywie doprowadziła do wzmocnienia się Francji. Klęską zakończyły się również próby negocjacji prowadzonych przez Albion. Porozumienie z października 1735 r. zostało ustalone bez brytyjskiej pomocy; również w kwestii rozejmu cesarza z Hiszpanią Albion nie odegrał istotnej roli.

\begin{abstract}
The aim of this article is to present the attitude of Great Britain to Spanish involvement in the war of Polish succession. Benjamin Keene, an envoy to Spain, played a key role in the British policy of that period. The British decided not to get involved in the conflict and from its first months tried to persuade Spain not to participate in it. Since 1734 , the British together with the Dutch tried to mediate for peace. However, these efforts proved to be ineffective and did not bring any benefits to Albion.
\end{abstract}

Keywords

Great Britain, Spain, war of polish succession. 